\title{
From anorthite to vesuvianite: an excursion through the minerals first discovered in Italy
}

\author{
Dipartimento di Scienze Mineralogiche e Petrologiche, Università di Torino, and Istituto di Geoscienze e Georisorse, CNR - Via Valperga \\ Caluso 35, 10125 Torino, Italy. <giovanni.ferraris@ unito.it><marco.ciriotti@libero.it>
}

\begin{abstract}
With regard to the number of mineral species first discovered in a particular country, Italy ranks fourth, being preceded only by USA, Russia and Germany. Important rock-forming minerals like analcime, anorthite, anorthoclase, antigorite, celadonite, diopside, dolomite, forsterite, humite, leucite, lime, lizardite, magnesiochloritoid, magnesite, nepheline, and sepiolite are among the 240 species first discovered in Italy. Other significant first Italian findings are some important index minerals of the UHP metamorphism (ellenbergerite, phosphoellenbergerite, magnesiodumortierite, and magnesiostaurolite; second occurrence of coesite) which were discovered in the well-known and first reported UHP outcrop of the Dora-Máira massif. Italy is also the native land of about 30 zeolites and of the two most abundant modern species: balangeroite and carlosturanite, which are rock-forming asbestos-like minerals of serpentinites in the western Alps.
\end{abstract}

\section{Introduction}

About 4500 reasonably well described geological chemical compounds and were recognized as species by the scientific community. It should be noted that in the mineralogical literature, thousands of "mineral names" cannot be related to well-defined compounds, but are just synonyms or refer to varieties (de Fourestier, 1999). These names should not be used according to the rules established by the Commission on New Minerals and Mineral Names (CNMMN) of the International Mineralogical Association (IMA) [cf. Nickel and Grice (1998) and the web site of the CNMMN http://www.geo.vu.nl/ users/ima-cnmmn/]. At the same time, an undefined number (not less than 1000?) of geological chemical compounds are sufficiently described in literature, but they have not been assigned a name; consequently they do not have the status of species. More than 50\% (i.e. about 2500) of the mineral species have been officially accepted by the CNMMN since its establishment in 1962 (cf. the quoted web site).

\section{National and regional records}

If countries are classified according to the number of mineral species first discovered in their territory, Italy, with its 240 species (at the end of 2002), ranks fourth with about $5.5 \%$ of species being preceded by USA $(\sim 15 \%)$, Russia $(\sim 14 \%)$, and Germany $(\sim 7 \%)$. Limiting the list to the countries with at least 100 first discovered species, Italy is followed by Canada $(\sim 4 \%)$, Sweden, UK,
Australia, China, France, and Japan. This classification certainly reflects well the activity, both past and present, of these particular countries in the search for new mineral species (sometimes, as amateur rather than a professional activity) than those countries' geochemical potentiality. It should be noted that in recent years well crystallized (or just rare) samples of minerals have became a good business and the leading countries are well known for hosting famous international fairs and trading mineral samples. Of course, the long established participation of a country in the science research is also important. Thus Italy boasts one species (sal ammoniac) described by Agricola in 1546, five other species (analcime, chabazite-Ca, dolomite, leucite, and vesuvianite) described in the XVIII century, and 74 in the XIX century. This group includes mainly species found by Scacchi (cf. Mottana, 2001) in the Vesuvius area. The group of the volcanic species has been further increased by Zambonini (1935). The historical record of Italy could certainly be improved if Plinius had quoted localities for the mineral species he mentioned. About 120 species have been described or redefined in the CNMMN era.

Guinness' records have always a touch of parochialism, consequently let us arrange the mineral species first discovered in Italy according to the Italian historical (now also administrative) regions. Of course, the regions are listed below with their Italian name, according to the number of species first discovered in each region. To give their Guinness' classification its proper scientific value, the chemical nature of minerals is shown as follows: silicates in heavy type; OXIDES IN SMALL CAPITALS; sulfides and sulfosalts underlined; organic compounds in italic; carbonates in heavy italic; other groups in normal type.

Campania (71): Anorthite, aphthitalite, avogadrite, bassanite, calciobetafite, carobbiite, chabazite-K, chlorothionite chalcocyanite, chloraluminite, chlormanganokalite, chlorocalcite, chloromagnesite, clinohumite, cotunnite, covellite, cryptohalite, cuprorivaite, cuspidine, cyanochroite, davyne, dimorphite I, dimorphite II, dolerophanite, eriochalcite, erythrosiderite, euchlorine, ferrohexahydrite, ferruccite, forsterite, haüyne, humite, kaliophilite, kremersite, leucite-high, leucite-low, LIME, litidionite, MAGNESIOFERRITE, malladrite, manganolangbeinite, marialite, mascagnite, matteuccite, meionite, melanothallite, mercallite, microsommite, misenite, mitscherlichite, molysite, montesommaite, monticellite, nahcolite, nepheline, palmierite, panunzite, PERICLASE, picromerite, potassic-fluorrichterite, pseudocotunnite, quadridavyne, sal ammoniac, sarcolite, scacchite, sylvite, TENORITE, vesuvianite, voltaite, ZIRCONOLITE- $3 O$, ZIRCONOLITE$3 T$.

Toscana (54): Ammonioborite, APUANITE, biringuccite, bonattite, BOTTINOITE, boussingaultite, BRIZZIITE, campigliaite, carraraite, cetineite, CLINOCERVANTITE, coquandite, dachiardite-Ca, DESSAUITE-(Y), dinite, elbaite, fiedlerite- $1 A$, franzinite, garavel$\underline{\text { lite, }}$ ginorite, grattarolaite, grumiplucite, ilvaite- $\boldsymbol{M}$, ilvaite- $\boldsymbol{O}$, larderellite, liottite, meneghinite, minguzzite, moëloite, mohrite, nasinite, onoratoite, pellouxite, peretaite, pillaite, pitiglianoite, pollucite, riomarinaite, rodolicoite, rosenbergite, ROSIAITE, rubicline, santabarbaraite, santite, sassolite, sborgite, scainiite, simonellite, STIBIVANITE- $2 O$, tuscanite, URANOPOLYCRASE, VERSILIAITE, zaccagnaite, zincalstibite. 
Piemonte (29): Antigorite, balangeroite, bavenite, bazzite, calcioancylite-(Nd), canavesite, carlosturanite, cascandite, cervandonite-(Ce), diopside, ellenbergerite, FETIASITE, gasparite-(Ce), GRAMACCIOLIITE- $(Y)$, jervisite, magnesiodumortierite, magnesiostaurolite, magnesite, monazite-(Nd), paracelsian, paraniite(Y), phosphoellenbergerite, roggianite, scandiobabingtonite, sepiolite, STRÜVERITE, taramellite, VIGEZZITE, wenkite.

Sicilia (19): Analcime-1C, analcime-1 $M$, analcime-1 $O$, analcime$1 Q$, anorthoclase-high, anorthoclase-low, barberiite, cannizzarite, chabazite-Na, fluoro-edenite, hieratite, magnesio-aubertite, MElanophlogite- $C$, MElanophlogite- $Q$, millosevichite, mozgovaite, phillipsite-Na, siderazot, sulfur- $\beta$.

Lazio (18): Alunite, cesanite, ciprianiite, gismondine-Ca, giuseppettite, hellandite-(Ce), katoite, latiumite, merlinoite, mottanaite-(Ce), peprossiite-(Ce), perrierite-(Ce), phillipsite-K, sacrofanite, spadaite, stoppaniite, vertumnite, vicanite-(Ce).

Liguria (14): Brewsterite-Ba, caoxite, cavoite, cerchiaraite, GRAVEGLIAITE, heulandite-Sr, medaite, mozartite, palenzonaite, reppiaite, saneroite, strontiopiemontite, tiragalloite, vanadomalayaite.

Veneto (9): Celadonite, cerussite, gmelinite-Ca, gmelinite-K, gmelinite-Na, heulandite-K, johannsenite, lizardite- $2 \mathrm{H}_{1}$, pectolite.

Sardegna (6): Barrerite, MONTEPONITE, ORLANDITE, rosasite, sabelliite, stilbite-Na.

Trentino-Alto Adige (5): Chabazite-Ca, dachiardite-Na, dolomite, gehlenite, pectolite.

Emilia-Romagna (4): Aliettite, jamborite, lizardite- $\mathbf{2} \mathrm{H}_{2}$, troilite.

Lombardia (4): Artinite, brugnatellite, chiavennite, sigismundite.

Val d'Aosta (4): Magnesiochloritoid, piemontite, ROMÉITE, STRONTIOMELANE.

Abruzzi (1): Refikite.

Friuli-Venezia Giulia (1): Bianchite.

Puglia (1): Francoanellite.

Umbria (1): Willhendersonite.

\section{From anorthite to vesuvianite}

To mention both anorthite and vesuvianite in the title of this article seems to involve both a journalistic touch (geological relevance of anorthite ... ; nearly first and last Italian species in alphabetical order ... ) and a recognition of Somma-Vesuvius volcanic complex, which is the most prolific Italian area for mineral species. It is unnecessary, of course, at this point to restate the role of plagioclases, including anorthite, in Earth Sciences, not to mention the difficulties students and researchers meet in characterising them exactly for the presence of twinning, exsolutions, etc. Presumably, the etymology of anorthite (from the Greek word for "oblique") applies not only to its morphology but also to its possibility of slanting from a correct interpretation.

\section{Geological records}

All mineral species have a scientific meaning in the sense that their occurrence, often in very limited amounts and in very restricted areas, is related to specific genetic and geochemical situations. Clearly, however, only a few of the mineral species reported above (but this can be extended to all known species) have wide prominence, not necessarily economic but at least relevant to the Earth Sciences.

\section{Dolomite-A mountain-forming mineral}

Thanks also to an earlier geological exploration of its territory, Italy is recognised as the motherland of some important rock-forming minerals like analcime, anorthite, anorthoclase, antigorite, celadonite, diopside, dolomite, forsterite, humite, leucite, lime, lizardite, magnesiochloritoid, magnesite, nepheline, and sepiolite. In particular, dolomite is a mountain-forming mineral!

\section{Index minerals of the UHP metamorphism}

Most of, if not all, the evidence for the attainment of UHP conditions by metamorphic rocks is a mineralogical one (cf. Chopin and Ferraris, 2003). In fact, some minerals by their nature, composition, texture or reactions, may be specific of such conditions. The coesite reported by Chopin (1984) from an outcrop of the Dora-Máira massif (western Alps) was already the second occurrence in the world but, correctly interpreted, opened a new era for modern Petrology and Earth Sciences in general. In fact, the presence of relics of a silica phase which is stable only at a pressure higher than about $3 \mathrm{GPa}$ showed that Dora-Máira outcrop had been uplifted from a depth of about $100 \mathrm{~km}$.

Coesite is not the only mineral which has contribution to telling yet unknown geological history of what is now among the most famous outcrops in the world. The first discovery of ellenbergerite, phosphoellenbergerite, magnesiodumortierite, and magnesiostaurolite; the occurrence of an almost Mg-pure magnesiochloritoid, the most $\mathrm{OH}$-rich wagnerite, and giant practically pure pyrope crystals; the second occurrence of bearthite, together with that of coesite. All these facts represent a proud record for the Italian Mineralogical Sciences, in general, and for the Dora-Máira massif in particular.

\section{Abundant minerals}

With very few exceptions, all new mineral species are found in small to very small quantities and they can be characterized only because powerful microanalytical methods are available to modern mineralogy. The adjective "abundant" can only be applied to four of the approximate total of 2500 modern species without risk of an overly subjective evaluation. Two of them are Italian minerals: carlosturanite and balangeroite (the other two are minrecordite and defernite, both from Namibia). These species were originally found in localities about $80 \mathrm{~km}$ apart in Piemonte. Both minerals are fibrous and always mistaken for chrysotile (Compagnoni et al., 1983, 1985).

In addition to the type locality of the Auriol asbestos mine, Sampeyre, Val Varaita, carlosturanite has been found in Taberg, Sweden, and abundantly in several fractured serpentinite outcrops in the western Alps. It is certainly the most abundant mineral approved by the CNMMN. Balangeroite has been found at the type locality of the Balangero asbestos mine (the largest one in western Europe) and in a few other localities in the same Lanzo Valley. The mineral occurs as tufts of brown xyloid fibers, more or less rigid, up to several $\mathrm{cm}$ in length. It was known as "metaxite" or "xilotile" by the miners from the Balangero mine. Neither massive serpentinites (where balangeroite is formed during the metamorphism of the ultramafic body) nor schistose serpentinites with short-fibre asbestos veins, were industrially exploited. They generally constituted the gangue material normally utilized for the mine constructions, and as granulates for road- and rail-beds, with the surplus dumped as waste. On the base of old miners' stories and data from the Amiantifera di Balangero S.p.A. historical archives, and considering the localisation in the deposit as well as the ubiquitous mingling with long-fibre chrysotile (50\%), it is probable that thousands of tons of balangeroite have been exploited together with chrysotile.

\section{Scandium minerals}

Baveno (Piemonte) is a well-known mineralogical locality of REE and rare mineral species such as: gadolinite- $(\mathrm{Ce})$, gadolinite- $(\mathrm{Y})$, hingganite-(Y), gugiaite, kaynosite-(Y), and calcioancylite-(Nd). In particular, Baveno is the type locality of bazzite the first discovered scandium mineral (Artini, 1915). Recently three other scandium minerals (jervisite, cascandite and scandiobabingtonite) were first reported from Baveno (Mellini et al., 1982; Orlandi et al., 1998). Thus, this locality accounts for 4 of the 14 known scandium minerals. 


\section{Mineral species and modern technology}

Zeolites are important minerals for modern technology because of their microporous activity (molecular sieves; cf. Gottardi and Galli, 1985). 30 (analcime- $1 C$, analcime- $1 M$, analcime- $1 O$, analcime- $1 Q$, barrerite, brewsterite-Ba, brewsterite- $\mathrm{Ca}$, chabazite- $\mathrm{Ca}$, chabazite$\mathrm{K}$, chabazite-Na, chiavennite, dachiardite-Ca, gismondine-Ca, gmelinite-Ca, gmelinite- $\mathrm{K}$, gmelinite-Na, heulandite-Ca, heulandite-K, heulandite-Sr, leucite-high, leucite-low, montesommaite, merlinoite, pectolite, phillipsite- $\mathrm{K}$, phillipsite-Na, roggianite, stilbite-Na, wenkite, and willhendersonite) out of about 90 known zeolites (Coombs et al., 1998) have their type locality in Italy.

Elbaite (tourmaline group) is worth mentioning for the exploitation of its piezoelectric effect. The sulfate palmierite gives its name to a structure-type module which alternates with perovskite-type modules in synthetic compounds with important physical properties, like superconductivity. Cotunnite is a type structure which is very popular in high-pressure solid-state research; recently a $\mathrm{TiO}_{2}$ phase with cotunnite-type structure and hardness comparable with that of diamond has been synthesized at about $60 \mathrm{GPa}$ and $1000 \mathrm{~K}$. Palmierite and cotunnite (both from Vesuvius), are not the only cases which demonstrate the precursor role of Mineralogical Crystallography in solid state science. Practically all type crystalline structures refer to a mineral species: from perovskite and spinel to diamond, rutile, and corundum, .... .

\section{References}

Artini, E., 1915, Due minerali di Baveno contenenti terre rare: weibyeïte e bazzite: Atti della Reale Accademia dei Lincei, Rendiconti della Classe di Scienze Fisiche, Matematiche e Naturali, Serie 5, v. 24, pp. 313-319.

Chopin, C., 1984, Coesite and pure pyrope in high-grade blueschists of the western Alps: a first record and some consequences: Contribution to Mineralogy and Petrology, v. 86, pp. 107-118.

Chopin, C., and Ferraris, G., 2003, Mineral chemistry and mineral reactions in UHPM rocks: EMU Notes in Mineralogy, in Carswell, D.A., and Compagnoni, R., eds, Ultra-high pressure metamorphism, v.5, in press.

Compagnoni, R., Ferraris, G., and Fiora, L., 1983, Balangeroite, a new fibrous silicate related to gageite from Balangero, Italy: The American Mineralogist, v. 68, pp. 214-219.

Compagnoni, R., Ferraris, G., and Mellini, M., 1985, Carlosturanite, a new asbestiform rock-forming silicate from Val Varaita, Italy: The American Mineralogist, v. 70, pp. 767-772.

Coombs, D.S. (Chairman) et al., 1997, Recommended nomenclature for zeolites minerals: Report of the subcommittee on zeolites of the International Mineralogical Association, Commission on New Minerals and Mineral Names: The Canadian Mineralogist, v. 35, pp. 1571-1606.

de Fourestier, J., 1999, Glossary of Mineral Synonyms: Mineralogical Association of Canada, Ottawa.

Gottardi, G., and Galli, E., 1985, Natural zeolites: Springer-Verlag, Berlin.

Mellini, M., Merlino, S., Orlandi, P., and Rinaldi, R., 1982, Cascandite and jervisite, two new scandium silicates from Baveno, Italy: The American Mineralogist, v. 67, pp. 599-603.

Mottana, A., 2001, Arcangelo Scacchi: massimo scopritore di minerali al Vesuvio: Università degli Studi di Napoli Federico II. Atti del Bicentenario del Real Museo Mineralogico (Eds. Ghiara, M.R., and Petti, C.), pp. 160-167.

Nickel, E.H., and Grice, J.D., 1998, The IMA Commission on New Minerals and Mineral Names: Procedures and guidelines on mineral nomenclature: The Canadian Mineralogist, v. 36, pp. 913-926.

Orlandi, P., Pasero, M., and Vezzalini, G., 1998, Scandiobabingtonite, a new mineral from the Baveno pegmatite, Piedmont, Italy: The American Mineralogist, v. 83, pp. 1330-1334.

Zambonini, F., 1935, Mineralogia vesuviana: Atti Reale Accademia delle Scienze di Napoli, Serie II, suppl. 20, 463 pages.
Giovanni Ferraris has been professor of Crystallography at the Faculty of Sciences of Torino University since 1975. Currently he is VicePresident of the Commission on New Minerals and Mineral Names of IMA and President of the Commission on Inorganic and Mineral Structures of IUCr. Born (1937) in Prarolo (Italy), he graduated in Physics (Torino University, 1960) and received the Libera Docenza in Crystallography (1969). Author of some 190 scientific papers and contributions to books, collaborated in the description of 29 new mineral species. Plinius medallist of the Italian Mineralogical and Petrologic Society and recipient of the Accademia dei Lincei Tartufari prize.

Marco Ciriotti is an amateur mineralogist, a "grouper", and a systematic collector. Born in Calosso (Italy, 1945), he graduated in Natural Sciences while working in industry. He pursued his career in industry until 2000 when, as General Manager, he retired. He then devoted himself to his primary interest and passion: mineral collecting and studies. He is the founder and the coordinator of the recently constituted AMI (Italian Micromineralogical Association), fellow of ICDD, SIMP, EcaSig5 and mineralogical associations. Author of articles on topological and structural mineralogy and of an unpublished mineral classification.
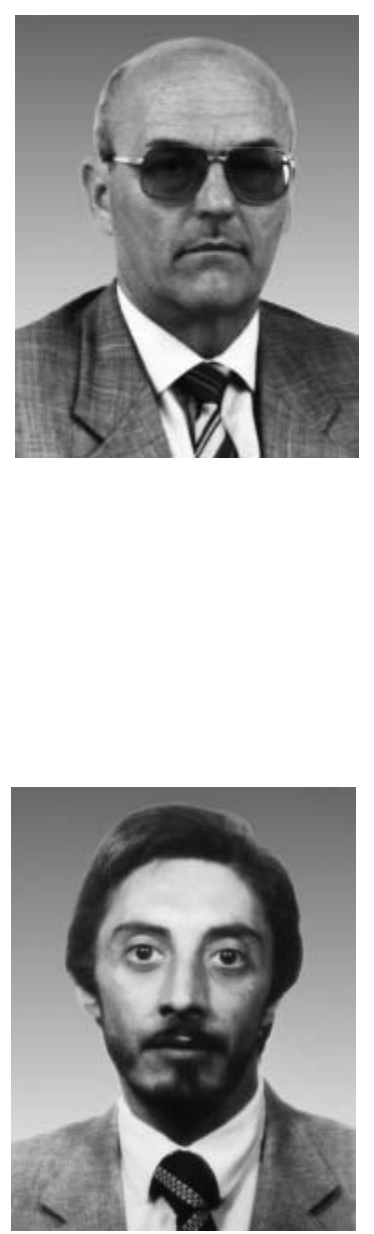